\title{
Ниццский договор и реформа судебной системы Европейских Сообществ
}

\section{Кривова М.В.*}

Вступление в силу Ниццского договора, подписанного в 2001 году', влечет за собой значительные изменения в построении и функционировании судебных учреждений Европейского Сообщества. Реформирование судебной системы ЕС рассчитано на длительный период, поскольку пересмотру подверглись не только основы ее построения, но и принципы судопроизводства и взаимодействия судов. Изменяются юрисдикция и порядок функционирования Суда ЕС и Суда первой инстанции (далее - СПИ). Отныне основные положения, касаюшиеся Суда первой инстанции, особенно его полномочий, инкорпорированы в сам договор. Кроме того, учредительный акт закрепляет положения, позволяющие создавать судебные палаты, которые должны будут рассматривать по первой инстанции споры, носящие узкоспециализированный характер.

Договор делает более гибкой систему внесения изменений в акты, регулирующие правовое положение и деятельность судов Сообщества, с тем чтобы обеспечить возможность ускоренной адаптации судебной системы к требованиям времени. Суд ЕС и Комиссия наделяются правом инициативы внесения изменений в Устав Суда ЕС, а поправки к Процессуальным регламентам судов или судебных палат отныне могут быть одобрены квалифицированным большинством голосов Совета.

Важным достижением Ниццского договора стало перераспределение компетенции между Судом ЕС и СПИ по делам прямой юрисдикции, а также наделение СПИ компетенцией по делам косвенной юрисдикции, которая раньше была исключительной прерогативой Суда ЕС. Кроме того, по решению Совета, принятому единогласно, суды Сообщества могут наделяться компетенцией выносить решения по делам в сфере прав интеллектуальной собственности, охраняемых на уровне Сообщества.

\footnotetext{
- Кривова Мария Владимировна - аспирантка кафедры европейского права МГИМО (У) МИД России.

${ }^{1}$ Ниццский договор вступил в силу $\mid$ февраля 2003 года.
} 
Ниццский договор не оставил также без внимания проблему формирования и внутренней структуры судов Сообшества, в частности это касается состава Суда ЕС, который претерпевает существенные изменения.

Важно отметить также укрепление роли Европейского Парламента, который, во-первых, получил статус «привилегированного истца» по искам об аннулировании, наравне с другими институтами Сообщества, а во-вторых, может запрашивать заключение Суда ЕС о соответствии учредительным договорам Сообщества соглашений, заключаемых Сообществом с третьими государствами или международными организациями.

Новый договор, таким образом, предпринял самую серьезную реформу судебной системы Сообщества с момента ее появления. Однако реализация на практике многих нововведений порождает немало весьма сложных проблем. Ниццский договор - это лишь первая ступень на пути перестройки судебной системы Сообщества, поскольку договор не коснулся многих важных моментов функционирования судов. Однако он создает правовую основу для их последуюшего урегулирования, в частности с помощью нового Устава Суда ЕС. Следовательно, можно ожидать, что реформа будет продолжена.

\section{1. Изменения, внесенные в Ниццский договор}

Как только Европейское политическое и правовое сообщество начало готовиться к межправительственной конференции 2000 года, многие были скептически настроены в отношении перспектив реформирования европейской судебной системы. Однако необходимость серьезного реформирования судебной системы обратила на себя внимание, несмотря на то, что эта проблематика даже не фигурировала среди прочих вопросов, которые в соответствии с Амстердамским договором нуждались в пересмотре до того, как произойдет расширение Европейского Союза.

Действительно, в течение долгого времени число обращений в Суд ЕС было весьма незначительным - сказывалось недоверие со стороны национальных судов и граждан государств-членов: в 1960 году, например, в Суд было подано всего лишь 23 иска. Постепенно объем работы увеличивался, и настал момент, когда решением Совета 88/5912 был

\footnotetext{
' СТ. 10 Ниццского договора признает это решение утратившим силу.
} 
учрежден Суд первой инстанции для того, чтобы способствовать снижению рабочей нагрузки на Суд ЕС. Однако в настоящее время и Суд $\mathrm{EC}$, и СПИ плохо справляются с постоянно увеличиваюшимся числом обращений, налицо перегруженность обоих судов: в 2000 году Судом ЕС и СПИ было зарегистрировано девятьсот обращений, причем каждый год число дел, поступающих в суды, намного превышает число вынесенных ими решений, что влечет за собой увеличение числа дел, находящихся в производстве, и, следовательно, затягивание сроков их разрешения. В среднем решения Суда ЕС приходится ждать в течение 21 месяца, а решения СПИ - целых 30 месяцев. Поэтому Суд ЕС однажды даже указал на то, что СПИ нарушил право сторон на судебное разбирательство в разумные сроки ${ }^{3}$.

Стало очевидно, что такое положение дел неприемлемо для нормального функционирования Сообщества в целом, кроме того, недопустимо, так как не соответствует представлениям о высоком уровне отправления правосудия. Более того, оно может даже усугубиться ввиду наделения судов новой компетенцией (в частности, в области интеллектуальной собственности), а также в связи с расширением Европейского Союза.

Уже в мае 1999 года Суд ЕС совместно с Судом первой инстанции представил документ под названием «Будущее судебной системы Европейского Союза (Предложения и размышления)» ${ }^{4}$, в котором говорилось о тревожной ситуации, связанной с перегрузкой судов работой, с постоянным ростом числа поступающих к ним исков и обращений. Кроме того, данный документ содержал предложения по реформированию судебной системы, в частности по созданию новых механизмов, которые позволили бы судам более эффективно справляться с поставленными перед ними задачами и адаптироваться к грядущему увеличению числа государств-членов Европейского Союза. Для изучения сложившейся непростой ситуации в области судопроизводства и оценки эффективности функционирования судов Сообщества Комиссия организовала Рабочую группу, которую возглавил бывший председатель Суда ЕС г-н Оле Дуэ. Рабочая группа представила результаты своей работы в конце января 2000 года ${ }^{5}$. Доклад Рабочей груп-

${ }^{3}$ См. решение Суда ЕС по делу С-185/95 от 17 декабря 1998 года Baustahlgewebe GmbH c. / Commission des Communautés européennes.

'L'avenir du système juridictionnel de l'Union Européenne (Document de réflexion). Locтупно на сайте Суда в Интернете http://www.curia.eu.int/en/txts/intergov/ave.pdf.

"A. Dashwood and A. Johnston (Eds.), "The future of the judicial system of the European 
пы содержал предложения по реформированию судебной системы, многие из которых Комиссия представила на межправительственной конференции 6 , заявив, что реформа судебной системы Сообщества действительно стала насущной необходимостью и что только так можно обеспечить качественную судебную защиту и уважение к правопорядку Сообщества на территории всех, в том числе и вновь присоединившихся государств-членов. Европейский совет в июне 2000 года подтвердил, что все государства-члены осознали необходимость уделить более пристальное внимание проблемам судебной системы Сообщества в Ницце.

Результаты межправительственной конференции в Ницце не стали сенсацией. По большей части спорных моментов было достигнуто согласие еще до начала политических обсуждений, что приветствовалось и широко освещалось средствами массовой информации, обсуждение более спорных вопросов, равно как и их решение, было отложено на будущее. Важно, однако, отметить, что большинство предложений по реформированию судебной системы на межправительственной конференции было учтено и закреплено в положениях Ниццского договора.

Существенным изменениям подверглись также тексты документов, дополняющих договор и регулирующих правовое положение Суда ЕС и СПИ. Протоколы об Уставе Суда ЕС, приложенные к Договору, учреждающему Европейское Сообщество, и к Договору о Евратоме, утрачивают силу и заменяются единым Уставом Суда ЕС, который отныне является неотьемлемой частью как двух упомянутых договоров, так и Договора о Европейском Союзе. Решение Совета ЕС 88/591/ЕОУС, ЕЭС, Евратом от 24 октября 1988 года, учреждающее Суд первой инстанции Европейских Сообществ, с поправками ${ }^{7}$, также теряет силу ${ }^{8}$. Положения, относящиеся к составу, организации и юрисдикции СПИ, поставлены теперь на один уровень с теми, которые относятся к Суду Union", Oxford, Hart Publishing, 2001, The Working Party Report. Ole Due. P. 87-94.

"Contribution Complémentaire de la Commission à la Conférence intergouvernementale sur les réformes institutionnelles. La réforme de la juridiction communautaire. Доступно в Интернете http://www.europa.eu.int/comm/archives/igc2000/offdoc/cont04022000_fr.pdf ${ }^{7}$ Первоначально было опубликовано в JO 1988, L 319/1, но в тексте обнаружилось большое количество неточностей, в связи с чем откорректированная версия была опубликована в JО 1989, С 215/1. Дальнейшие изменения были направлены на расширение полномочий СПИ: см. решения Совета 93/350, JО 1993, L 144/21 и 94/149, JO 1994, L $66 / 29$.

${ }^{8} \mathrm{C}$. 10 Ниццского договора. 
ЕС, как в текстах самих договоров, так и в Уставе. Было предусмотрено, что к Договору о ЕОУС будут применяться переходные положения до момента прекрашения его действия в 2002 году ${ }^{9}$. Одновременно с этим было произведено упорядочение перекрестных ссылок между различными положениями, с тем чтобы обеспечить согласованность текстов в связи с внесением в них изменений.

\section{2. Положения, касающиеся внесения изменений в Устав Суда ЕС, Процессуальные регламенты судов и судебных палат}

На межправительственной конференции, предшествовавшей подписанию Ниццского договора, Судом ЕС и СПИ было выдвинуто предложение об упрощении процедуры внесения изменений в документы, регулирующие их правовое положение. Пожелание судов было учтено: в договоре закреплены только фундаментальные принципы организации и деятельности судов, он содержит большое количество диспозитивных норм, которые позволяют детализировать договорные положения в Уставе Суда ЕС. Так, например, новая статья 221 Договора о ЕС (далее - ДЕС) значительно упрощает процедуру структурирования Суда ЕС, поскольку предусматривает, что «Суд ЕС заседает в составе Палат или Большой палаты в соответствии с правилами, предусмотренными на этот счет Уставом Суда ЕС». Подобный подход применен в отношении большинства статей Договора, посвященных судам Сообщества.

Несмотря на то, что Устав Суда ЕС содержится в протоколе, прилагаемом к Ниццскому договору, и как таковой имеет статус источника первичного права ЕС, новая статья 245 ДЕС допускает внесение поправок в некоторые его положения (исключение составляют положения главы I Устава) путем принятия Советом единогласного решения. Таким образом, для изменения положений Устава больше не требуется созыва межправительственной конференции. Совет принимает со-

\footnotetext{
${ }^{9}$ Путем оставления в силе статьи 3 решения 88/581/ЕОУС, ЕЭС, Евратом в той мере, в которой СПИ осуществляет полномочия Суда ЕС по Договору о ЕОУС. В то же время к ЕОУС должны были применяться также и положения единого Статута, а статьи 1-20, 44, 45, 46 (второй и третий параграфы), 47-49, 51, 52, 54 и 55 Устава Суда ЕОУС утрачивали силу (ст. 8 Ниццского договора). Договор о ЕОУС прекратил действие с 23 июля 2002 г.
} 
ответствующее решение либо по требованию Суда ЕС и после консультаций с Комиссией и Парламентом, либо по инициативе Комиссии и после консультаций с Судом ЕС и Европарламентом. Стоит отметить, что право инициативы, а также консультационная процедура с центральной ролью Суда ЕС и Комиссии будут применяться в соответствии с новой статьей 225 А ДЕС, регулирующей правовое положение судебных палат.

Для Суда ЕС и СПИ важное значение имело также придание большей гибкости процедуре внесения изменений в Процессуальные регламенты, которая существовала до того момента. И действительно, Суд $\mathrm{EC}$, вдохновленный моделью Европейского суда по правам человека (ЕСПЧ) в Страсбурге, выдвинул предложение о том, чтобы ему было предоставлено право самостоятельно принимать свой Процессуальный регламент или, по крайней мере, чтобы Совет мог принимать решение квалифицированным большинством голосов, а не единогласно, так как раньше внесение в регламент даже незначительных изменений требовало много времени ${ }^{10}$. Государства-члены не пожелали наделить суды таким контролем в отношении их деятельности, однако согласились на минимальные уступки: отныне изменения в Процессуальные регламенты судов могут быть внесены, если Совет одобрит их квалифицированным большинством голосов. При этом Суду ЕС позволено самостоятельно разрабатывать свой Процессуальный регламент, а СПИ по-прежнему должен при разработке своего регламента получить согласие Суда $\mathrm{EC}$, прежде чем направить его на утверждение Совету. Эга реформа отражена в новых статьях 223 и 224 ДЕС. Получить одобрение Суда ЕС должна и каждая учрежденная Советом судебная палата (новая статья 225 А ДЕС).

Вкпючение в договор положений о том, что поправки в Процессуальные регламенты судов ЕС могут вноситься путем принятия Советом соответствуюшего решения квалифицированным большинством голосов, стало возможным после перенесения в Устав Суда ЕС такого политически болезненного вопроса, как лингвистический режим. Положения, касающиеся лингвистического режима Суда ЕС и СПИ, в настоящее время закреплены в Процессуальных регламентах этих судов (статъи 29-31 и 35-37 соответственно). Если бы эти положения не были перенесены в Устав Суда, изменения в который отныне могут вноситься Советом единогласно, то Совет получил бы возможность ${ }^{10} \mathrm{CM}$. сноску 4. 
в силу новой статьи 223(6) ДЕС и новой статьи 224(5) ДЕС вносить изменения в эти положения квалифицированным большинством голосов. В целях сохранения правила, требуюшего единогласного решения Совета по вопросам о лингвистическом режиме судов (которое в силу статьи 290 ДЕС применяется также и в отношении лингвистического режима других институтов Сообщества), отныне в новой статье 290 ДЕС ссылка делается не на Процессуальные регламенты, а на Устав Суда ЕC" .

\section{3. Изменения, касающиеся Суда первой инстанции}

Ницшский договор значительно укрепил позиции СТИ. Изменениям подверглась статья 220 ДЕС. Теперь наравне с Судом ЕС СПИ призван обеспечивать «применение права Сообщества посредством единообразного толкования и применения настоящего договора». Таким образом, его существование впервые юридически закреплено, а не просто упомянуто, как было раньше: «Суду ЕС придается Суд...», то есть из органа, который может быть создан по решению Совета, Суд первой инстанции трансформируется в орган, учрежденный договором. Переход от статуса простого «придатка» Суда ЕС к статусу самостоятельного судебного органа соответствует возрастающему грузу ответственности, который несет на своих плечах Суд первой инстанции.

Рассмотрим наиболее существенные изменения.

\section{1. Дела прямой юрисдикции}

Первоначально юрисдикция СПИ распространялась лишь на узкоспециализированную, требуюшую больших временных затрат категорию дел, например трудовые споры между служащими Сообщества и Сообществом. Показав способность зффективно справляться с такого рода делами, СПИ постепенно получил право выносить решения и по более важным вопросам.

\footnotetext{
"СТ. 64 нового Устава Суда ЕС запрещает внесение поправок в положения, касающиеся лингвистического режима Суда ЕС и СПИ, квалифицированным большинством голосов Совета в течение промежуточного периода, необходимого для закрепления положений о лингвистическом режиме этих судов в Уставе, прямо предписывая, что соответствуюшие положения Процессуальных регламентов могут быть изменены или отменены путем применения процелуры, предусмотренной для внесения изменений в Устав, т.е. единогласным решением Совета (см. новую редакіию ст. 245 ДЕС).
} 
Новая статья 225 ДЕС гласит, что СПИ компетентен рассматривать в первой инстанции «иски, предусмотренные статьей 230 [об аннулировании], 232 [иски о возмешении ущерба], 235 [иски о внедоговорной ответственности], 236 [иски, вытекающие из споров между должностными лицами Сообщества и Сообществом], 238 [иски о договорной ответственности], за исключением тех, которые подпадают под компетенцию судебньх палат, и тех, которые Устав относит к компетеншии Суда ЕС». Таким образом, несмотря на то, что компетенция СПИ не распространилась на иски о неисполнении обязательств (статья 226-228 ДЕС), которые по-прежнему компетентен рассматривать только Суд ЕС, Суд первой инстанции приобретает статус суда общей юрисдикщии, рассматривающего по первой инстанции любые категории исков.

Статья 225(1) ДЕС содержит положение, которое исключает из-под юрисдикции СПИ дела, подпадающие под юрисдикцию Суда ЕС, если так предусмотрено в Уставе. Это и было сделано: статья 51 Устава Суда делает особое ударение на то, что любой иск, поданный одним из институтов Сообщества, Европейским Центральным Банком или государством-членом будет подпадать автоматически под юрнсдикщию Суда ЕС; даже если эти сферы относятся к юрисдикции СПИ в соответствии со статьей 225 ДЕС. Однако стоит заметить, что, поскольку все возможные исключения определены в Уставе, Совет ЕС имеет возможность в будущем путем принятия единогласного решения вносить в него поправки. Межправительственная конференция призвала «Суд ЕС и Комиссию высказать как можно быстрее свои соображения в отношении перераспределения компетенции между Судом ЕС и Судом первой инстанции в сфере искового производства и представить на рассмотрение компетентным институтам ЕС приемлемые предложения для изучения, как только вступит в силу Ниццский договор $\rangle^{12}$.

В настоящее время Комиссия, изучив позицию Суда ЕС, основанную «на статистическом и материальном анализе исков, поданных в течение последних пяти лет (1996-2000) институтами Сообщества и государствами-членами», представила на рассмотрение Совета свое заключение ${ }^{13}$. Суд ЕС предложил оставить в собственном ведении иски

\footnotetext{
12 Декларация 12 к Заключительному акту межправительственной конференции о статье 225 Договора, учреждающего Европейское Сообщество, JО 2001, С-80/1, Р. 79.

${ }^{13}$ Avis de la Commission sur la demande de modification de l'article 51 du Statut de la Cour de justice, presentée par la Cour en réponse à la déclaration n?12 au traité de Nice, relative à l'article 225 du traité CE, modifié par le traité de Nice. Bruxelles, le 20.9.2002 SEC (2002) 994 final 2002/0226 (CNS)
} 
о6 аннулировании и о возмещении ущерба против Совета или Парламента или против этих двух институтов одновременно, поданные государствами-членами, институтами Сообшества и Европейским Центральным Банком, а также иски к Комиссии и ЕЦБ, если они поданы одним из институтов Сообщества. При этом предусматривалось передать в ведение СПИ иски к Комиссии или к ЕЦБ об аннулировании и о возмешении ущерба, поступаюшие от государств-членов. Комиссия не согласилась с мотивировками Суда $\mathrm{EC}^{14}$ и предложила следующее: передать под юрисдикцию Суда ЕС иски об аннулировании и о возмешении ушерба, поданные государствами-членами, институтами Сообщества или ЕЦБ против акта, принятого в силу Договора, учреждающего Сообщество, или против воздержания от принятия акта, предусмотренного Договором, за исключением решений, принятых Комиссией или Советом в силу статьи 88(2) Договора о ЕС (государственная помошь), и решений, принятых Комиссией в силу статьи 38 (компенсационные сборы), статьи 76(2) (транспортные тарифы), статей 81,82 , $85,86(3)$ (право конкуренции) и статьи 134 (общая торговая политика) Договора, учреждающего Европейское Сообщество. Однако иски, основанные на положениях перечисленных статей, если они поданы одним институтом Сообщества против другого, либо ЕЦБ, институтами и органами, учрежденными Договором о ЕС или на его основе, автоматически подпадают под юрисдикцию Суда ЕС.

Таким образом, Суд ЕС, пытаясь найти четкий и недвусмысленный критерий для распределения полномочий между ним и СПИ по делам прямой юрисдикции, придерживался того мнения, что за ним должна сохраниться роль квази-конституционного суда, которой соответствует компетенция по контролю над основной законотворческой деятельностью и по решению межинституционных конфликтов. Комиссия, также подчеркивая важную роль Суда ЕC, посчитала, что критерий перераспределения компетенции, зависящий от статуса ответчика, не в полной мере отвечает целям Ниццского договора, поскольку, по мне-

${ }^{14}$ Так, Суд, основываясь на статистических данных, указывал на то, что, например, из 132 исков об аннулировании актов Комиссии, поступивших в период с 1996 по 2000 год, 122 иска носили технический характер, и не было оснований, оправдываюших их рассмотрение в Суде ЕС. В то же время Суд указывал на необходимость внесения изменений в ст. 54 Устава, которая позволяла бы в случае одновременного рассмотрения двух связанных исков в Суде ЕС и СПИ (например, иск против регламента Совета и иск против регламента Комиссии, направленного на его исполнение) Суду первой инстанции передать дело, находящееся в его производстве, на рассмотрение Суда ЕС. 
нию Комиссии, его применение может привести к неоправданному сохранению под юрисдикцией Суда ЕС некоторых категорий исков, которые могут рассматриваться СПИ, и, наоборот, СПИ получит право рассматривать споры, которые должен рассматривать исключительно Суд ЕС. Однако Совет еще не принял окончательного решения по предложению Комиссии, и, соответственно, вопрос о перераспределении прямой юрисдикции между Судом ЕС и СПИ остается открытым.

\section{2. Создание судебных палат}

В настоящее время сложилась такая ситуация, при которой учрежденный в 1988 году для облегчения бремени Суда ЕС Суд первой инстанции сам с трудом стал справляться с поступающей к нему массой исков. С целью облегчить работу СПИ Ниццский договор предусматривает в новой статье 225 А ДЕС создание независимых ${ }^{15}$ судебных палат для рассмотрения узкоспециализированных споров. Палаты будут приданы СПИ, как в свое время СПИ был придан Суду ЕС.

Учитывая те сложности, которые испытывает сейча̀с СПИ ${ }^{16}$, в Декларации № 16, приложенной к Ниццскому договору, прямо предусматривается создание судебной палаты для рассмотрения по первой инстанции трудовых споров между служащими Сообщества и Сообществом. Комиссия призвана совместно с Судом ЕС «в кратчайшие сроки подготовить приемлемый проект решения, учреждаюшего судебную палату, компетентную выносить решения по первой инстанции по трудовым спорам между Сообществом и его служащими» ${ }^{17}$, и в кратчайшие сроки представить этот проект на рассмотрение Совета. Решение Совета, принятое единогласно, по предложению Комиссии и после консультаций с Судом ЕС и Европарламентом либо по предложению Суда ЕС и после консультаций с Европарламентом и Комиссией позволит учредить судебную палату с узкой специализацией. Такое ре-

\footnotetext{
${ }^{15}$ Речь идет о предоставлении этим судебным палатам статуса независимых судебных учреждений в смысле ст. 6 І Европейской конвенции о правах человека or 4 ноября 1950 г.

${ }^{16}$ Статнстика свидетельствует, что трудовые споры с участием служащих и должностных лиц представляют собой серьезную нагрузку на СПИ: по состоянию на 31 декабря 1999 года именно по зтим спорам было самое большое число неоконченных дел (69), а средняя продолжительность рассмотрения дел этой категории одна из самых высокнх (17 месяцев).

17 Декларация 16 к Заключительному акту межправительственной конференции по статье 225 Договора, учреждающего Евролейское Сообщество J.О. 2001, С 80/1, Р. 80.
} 
шение должно также содержать правила, определяюшие состав судебной палаты и пределы предоставленной ей компетенции. К судебной палате в равной степени применяются все положения Устава Суда $\mathrm{EC}$, если Совет в своем решении прямо не предусмотрит иное. В соответствии с новой статьей 225 А ДЕС судебные палаты будут состоять из лиц, обладающих независимостью и отвечающих требованиям, необходимым для занятия судейских должностей, назначаемых Советом единогласно. Судебная палата, специализирующаяся на рассмотрении трудовьг споров между служащими Сообщества и Сообществом, возможно, получит также право проводить примирительные процедуры ${ }^{18}$.

Учреждение других судебных палат должно происходить постепенно. СПИ, кроме прочего, в настоящее время уполномочен рассматривать споры, касающиеся регистрации марки на уровне Сообщества. Несмотря на то, что СПИ вынес всего лишь несколько решений по делам о европейской марке, Бюро по гармонизации на внутреннем рынке (Office de l'harmonisation dans le marché intérieur) (далее - БГВР) ${ }^{19}$ считает, что число обрашений в СПИ быстро достигнет 200-400 в год ${ }^{20}$. В этом контексте Доклад Рабочей группы содержит предложение о переформировании палат по обжалованию, входящих в состав БГВР, в настоящие судебные палаты, хотя в Договоре по этому поводу не сказано ничего определенного. Важно, что Люксембург выступил с односторонним заявлением о том, что он не будет требовать изменения местоположения палат по обжалованию БГВР из Аликанте (Испания) «также в том случае, если они будут преобразованы в судебные палаты ${ }^{21}$.

Параграф 2 статьи 225 ДЕС наделил СПИ новым полномочием, позволяюшим ему пересматривать решения судебных палат примерно как сейчас СПИ пересматривает решения, вынесенные палатами по обжалованию (chambres de recours) БГВР. Важно то, что решения таких палат по вопросам, находящимся в сфере их специализации, могут подлежать пересмотру со стороны СПИ только по вопросам права, если само решение об учреждении палаты не предусматривает

${ }^{18} \mathrm{La}$ Contribution de la CJ et le TPI a la CIG, point 4 . Доступно на сайте Суда ЕС в Интернете http:/www.curia.eu.int/fr/instit/txtdocfr/autrestxts/cig.pdf.

19 Учреждено в соответствии с Регламентом Совета № 40/94 от 20 декабря 1993 г. европейской марке (JO 1994, L 11, Р. 1).

${ }^{20}$ Propositions présentées par la Cour et le Tribunal pour les nouveaux contentieux de la propriété intellectuelle. Доступно на сайте Суда ЕС в Интернете

${ }^{21}$ Декларация Люксембурга, приложенная к Ниццскому договору. 
возможности пересмотра фактических обстоятельств дела. Таким образом, СПИ может осуществлять как функции суда последней инстанции (кассационного), так и суда апелляционной инстанции.

\section{3. Преюдициальная юрисдикция}

Одним из достижений Ниццского договора является положение, закрепленное в новой статье $225(3)$ ДЕС, позволяющее СПИ рассматривать и принимать решение по вопросам преюдициального характера, поступающим к нему в силу статьи 234 ЕС в специфических областях, определенных Уставом Суда ЕС.

Долгое время опирающаяся на поддержку доктрины монополия Суда ЕС в сфере преюдициальной юрисдикции постепенно стала для него тяжелым бременем. Так, в 1999 году в Суд ЕС поступило 225 вопросов преюдициального характера, по 394 вопросам Судом ЕС так и не было вынесено решения. Из этого следовало, что необходимо создать такой механизм, который поможет Суду ЕС справиться с возникшей проблемой. На межправительственной конференции предлагались различные варианты решений. Одно из них - позволение национальным судебным органам одновременно с вопросом направлять в Суд ЕС также и предлагаемый ответ, что, возможно, поставило бы под сомнение существование самой преюдициальной процедуры. Ограничение числа судебных учреждений, имеющих право обрашаться в Суд ЕС, идет вразрез с принципом сотрудничества между судьями национального и европейского уровня, а именно такое сотрудничество является отличительной чертой преюдициальной процедуры. Тем не менее, было найдено принципиальное решение, закрепленное в новой статье 225(3) ДЕС, которое позволяет передавать СПИ компетенцию по рассмотрению вопросов преюдициального характера в специфических областях, определенных Уставом Суда ЕС, если будет ощушаться такая необходимость.

В настоящий момент Устав Суда ЕС не определяет, на какие специфические сферы распространится новая компетенция СПИ. Учитывая то, что обращения, требующие рассмотрения в рамках преюдициального производства, представляют собой серьезную нагрузку на Суд $\mathrm{EC}$, очень вероятно, что Суд ЕС потребует внесения изменений в Устав и передачи СПИ части полномочий в этой сфере. Вероятно, поскольку СПИ уже рассматривает жалобы, поступающие от Апелляционного комитета БГВР в Аликанте, связанные с применением Регла- 
мента EC о европейских торговых марках ${ }^{22}$, на ранней стадии реформы СПИ будет уполномочен рассматривать в рамках преюдициальной процедуры именно вопросы, связанные с реализацией Первой директивы Совета ЕС о гармонизации законодательств государств-членов в сфере торговых марок ${ }^{23}$.

\section{4. Пересмотр решений СПИ}

Практическое применение положений Ниццского договора, касаюшихся возможности пересмотра решения СПИ, вызвало довольно острую дискуссию.

Во-первых, сложная проблема возникает в силу новой статьи 225 ДЕС, которая уполномочивает СПИ пересматривать решения судебных палат, поскольку «в исключительных случаях» решение самого СПИ также может стать предметом пересмотра в Суде ЕС, «если существует серьезная угроза единству и целостности права Сообщества» (статья 225(2) ДЕС). Статья 62 Устава разьясняет, что определение того, существует ли такая угроза или нет, будет входить в обязанность Первого генерального адвоката (определить это он должен в течение одного месяца с момента вынесения СПИ своего решения). Если Первый генеральный адвокат посчитает, что угроза есть, то он может предложить Суду ЕС пересмотреть решение СПИ. Суд ЕС должен в течение одного месяца после получения мнения Первого генерального адвоката определить, будет ли иметь место пересмотр решения СПИ. Очевидно, что установление строгих временных рамок направлено на снижение риска чрезмерного затягивания самого процесса рассмотрения такого рода дел на уровне судов Сообщества, хотя привлечение Первого генерального адвоката к участию в данном процессе необходимо для того, чтобы не отнимать значительного времени на выработку подобных определений у Председателя Суда ЕС. В общем, такая система фильтрации должна позволить эффективно справляться с проблемой, существующей в области трудовых споров с участием служаших Сообщества, которая состоит в следующем. Поскольку служащие Сообщества не должны оплачивать судебные издержки, появилась тенденция, когда обиженный служаший обжалует каждое решение и доходит таким образом до самых высоких инстанций. Несмотря на это, некоторые из государств-членов по-прежнему считают, что разреше-

22 Регламент Совета № 40/94 от 20 декабря 1993 г. европейской марке (JО 1994, L 11, Р. 1).

${ }^{23}$ Первая директива Совета 89/104/ЕЭС от 21 декабря 1988 г. (JO 1989, L 40, Р. 1). 
ние обжаловать решение СПИ, вынесенное против решения судебной палаты, сведет на нет все усилия, направленные на разгрузку Суда ЕC, в частности, от трудовых споров с участием служаших Сообщества, и поддерживают идею, что СПИ должен быть в таких делах судом последней инстанции (решения которого могут быть пересмотрены в Суде EC только «в интересах права» по требованию Комиссии, что не должно влиять на результат, достигнутый при рассмотрении спора).

Во-вторых, наблюдается расплывчатость в регулировании процедуры пересмотра (de reexamen) и передачи дела на рассмотрение в Суд EC (de renvoi). Договор закрепил две возможности прибегнуть к процедуре пересмотра решения в Суде ЕС «в случае серьезной угрозы единству и целостности права Сообщества». Первая такая возможность позволяет пересматривать решения СПИ, вынесенные по жалобе на решения судебных палат, о чем речь шла выше. Вторая процедура пересмотра действует в отношении решений СПИ по вопросам преюдициального характера. А ведь в этой области СПИ, «когда он посчитает, что дело требует принципиального решения, способного затронуть единство и целостность права Сообщества, может передать его на рассмотрение в Суд ЕС» (статья 225(3) абз.2 ДЕС). Что же произойдет, если СПИ направит дело на рассмотрение в Суд ЕС, который посчитает, что оно не затрагивает целостности и последовательности права Сообщества? Будет ли сам Суд ЕС рассматривать это дело или оно направится на новое рассмотрение в СПИ, что, без сомнения, скажется на продолжительности всей процедуры?

Не рискует ли быть затронутой целостность права Сообщества каждый раз, когда СПИ будет объявлять недействительным правовой акт Сообщества? При этом не нужно ли будет СПИ, если он почувствует серьезные сомнения в законности обжалуемого акта, сразу же направить это дело на рассмотрение в Суд ЕС? Тем временем новая статья 225(3) абз.2 ДЕС предусматривает лишь возможность, а не обязательство СПИ направлять дело в Суд ЕС при возникновении указанных сомнений. Но главное, взаимосвязь процедуры пересмотра и процедуры передачи дела на рассмотрение в Суд ЕС представляется совершенно непоследовательной. Условия процедуры пересмотра должны быть урегулированы в Уставе Суда ЕС. В частности, для этого необходимо указать, кто именно может начать такую процедуру. Очевидно, такое право будет предоставлено судебному органу, который направляет дело в Суд ЕС. Тогда было бы предпочтительно установить обя- 
зательство для СПИ направлять дело на рассмотрение Суда ЕС каждый раз, когда его решение может затронуть единство и целостность права Сообщества. Это позволило бы национальным судебным учреждениям не дожидаться решения СПИ для того, чтобы потом их дело было пересмотрено Судом ЕС. И действительно, даже использование срочной процедуры пересмотра решений СПИ ${ }^{24}$ лишь частично решает проблему потери времени национальным судебным органом.

Суд ЕС, до того как приступить к решению вопроса по существу, должен будет определить, существует ли реальная угроза единству и целостности права Сообшества. Какие последствия будет иметь пересмотр Судом ЕС решения СПИ для исполнительной силы такого решения, должно быть указано в Уставе Суда $\mathrm{EC}^{25}$. Положения, касающиеся пределов и условий обжалования решений СПИ в Суде $\mathrm{EC}$, также регулируются Уставом Суда. В этой связи необходимо вспомнить, что межправительственная конференция поручила Совету, как только он одобрит положения Устава Суда EC, необходимые для применения статьи 225(2) и(3) ДЕС, разработать и внедрить процедуру, позволяющую обеспечить переоценку этих положений самое позднее через три года после их вступления в силу ${ }^{26}$.

\section{5. Проблема защиты прав интеллектуальной собственности}

Новая статья 229 А ДЕС позволяет Совету вынесенным единогласно решением по предложению Комиссии и после консультаций с Европейским ПТарламентом наделить судебные учреждения ЕС полномочием рассматривать споры, связанные с применением актов, принятых на основании Договора, учреждающего Европейское Сообщество, создающих и регулирующих права интеллектуальной собственности

${ }^{24}$ Декларация №15 о статье 225(3) Договора, учреждающего Европейское Сообщество, к Заключительному акту межправительственной конференции в Ницце.

is В Декларации №13 о статье 225(2) и (3) Договора, учреждающего Европейское Сообщество, к Заключительному акту межправительственной конференции сказано, что Устав Суда должен также прояснить, какую роль будут иметь стороны в споре, который будет направлен на пересмотр в Суд ЕС, с тем чтобы обеспечить зашиту их прав, а также последствия решения Суда ЕС для самого спора между сторонами. Эти предложения кажутся малоприменимыми к преюдициальной процедуре, по которой слоров не возникает, но больше касающимися процедуры пересмотра решений СПИ, вынесенных против решений судебных палат (палаты по обжалованию решений БГВР). ${ }^{2 \kappa}$ Декларация № 14 о статье 225(2) и (3) Договора, учреждающего Европейское Сообщество, к Заключительному акту межправительственной конференции в Ницце. 
Сообщества. Решение Совета должно быть ратифицировано государствами-членами. Межправительственная конференция не предопределила выбор судебной инстанции, которая должна будет рассматривать данную категорию споров, оставив это решение за Советом ${ }^{27}$.

Положения статьи 229 А ДЕС, возможно, найдут свое применение в отношении европейского патента. Так, Комиссия в одном из рабочих документов ${ }^{28}$ высказалась по этому поводу следуюшим образом.

Комиссия считает, что специализированный в области патентного права судебный орган Сообщества сможет как нельзя лучше гарантировать единство применения соответствуюших положений и последовательность судебной практики в сфере единого европейского патента. Единый европейский патент должен будет не только выдаваться на основе единообразных положений, закрепленных в Конвенции, но и получить качественную, недорогую, быструю и единообразную судебную защиту на уровне Сообщества. Европейские предприятия и компании смогут избежать, таким образом, необходимости участвовать в затянутых, дорогостоящих разбирательствах в судах различных государств-членов.

Таким образом, споры, которые будут передаваться специализированному судебному органу Сообщества, будут представлять собой споры между частными лицами, что, соответственно, исключает юрисдикцию Суда ЕС. В этом случае логично использовать возможности, которые представила новая статья 225 А ДЕС, позволяющая создавать специализированные судебные палаты. Такая палата, специализированный патентный суд, будет придана СПИ, который, в свою очередь, будет рассматривать жалобы на ее решения.

\section{4. Состав и внутренняя структура судов}

Реформирование положений, касающихся состава и формирования Суда ЕС, было вызвано необходимостью подготовки судебных учреждений к предстоящему расширению, которое повлечет за собой принятие новых государств-членов в Европейский Союз. Однако также было необходимо сделать работу судов более гибкой и рациональной.

\footnotetext{
${ }^{27}$ Декларация № 17 о статье 229 А Договора, учреждающего Европейское Сообщество, к Заключительному акту межправительственной конференции в Ницце.

${ }^{28}$ Document de travail de la Commission sur la juridiction prévue en matière de brevet communautaire, Bruxelles, le 30.08.2002 COM (2002) 480 final.
} 
Межправительственная конференция столкнулась с проблемой обеспечения равного представительства государств-членов в учреждениях ЕС в условиях расширения Евросоюза. Урегулирование этой проблемы требовало нелегкого политического решения, которое вызвало немало критики в свой адрес. Поэтому реформа положений, касающихся состава и внутренней структуры судов Сообщества, также нуждается в доработке.

Статья 221 ДЕС предусматривает, что «Суд ЕС должен состоять из одного судьи от каждого государства-члена» ${ }^{29}$. Следовательно, число судей Суда ЕС напрямую зависит от количества государств-членов: правопорядок каждой страны имеет право быть представленным в Суде, и именно так можно обеспечить легитимность его решений. В окончательном варианте Договора этот принцип был четко закреплен. Такая формулировка вполне приемлема и нацелена на будущее расширение Европейского Союза: отныне не нужно будет каждый раз вносить изменение в это правило с присоединением каждого нового государства-члена. Также сам процесс расширения позволит большему количеству судей эффективнее справляться с возрастающим количеством исков, которые неминуемо будут возникать с присоединением каждого нового государства-члена. Важно подчеркнуть, что судьи не должны рассматриваться как политические представители своих государств, при их назначении может применяться единственный критерий-профессионализм.

Статья 221 ДЕС, таким образом, предусматривает общие правила, касаюшиеся формирования и внутренней структуры Суда ЕС, предоставляя Уставу более детально урегулировать эти положения. Статьи 16 и 17 нового Устава Суда предусматривают следуюшее: Палата должна состоять из трех или пяти судей ${ }^{30}$, кворум для которых будут составлять три судьи. Однако если в деле участвует государство-член

${ }^{29} \mathrm{~B}$ результате процесса расширения Европейского Союза число судей Суда ЕС может стать четным. Сложность, возникающая в связи с необходимостыю соблюдения принципа, согласно которому решение ситтается законным, только если оно вынесено нечетным числом судей (отсюда и проблема, которая возникла в 1995 году, тогда Италия была представлена двумя судьями дия того, чтобы соблюсти требование о нечетном числе судей), может быть преодолена путем фиксирования числа судей, составляющих соответствующий кворум: если в слушании дела принимает участие одиннадщать судей, то Суд в полном составе может выносить решение (ст. 17 Устава Суда ЕС).

${ }^{30}$ Определенно вопрос об учреждении палаты из семи судей отпадет сам собой, поскольку в такой палате нет никаких значительных преимуществ перед комбинацией: Большая палата - палаты из пяти судей. 
или один из институтов Сообщества (в качестве истца либо ответчика), эти стороны могут ходатайствовать о рассмотрении их дела Большой Палатой, состоящей из одиннадщати судей, кворум для которой будет равен девяти судьям. Пленум Суда (с кворумом в одиннадцать судей) будет собираться для рассмотрения дел только в исключительных случаях: статья 16 Устава требует этого в случаях, предусмотренных статьями 195(2), 213 и 247(7) ДЕС, которые включают в себя отставку Омбудсмена Европейского Парламента, отставку или лишение пособия или других привилегий члена Комиссии, серьезный проступок со стороны члена Комиссии, а также отставку или лишение пособия или других привилегий члена Счетной Палаты. Каждый из этих случаев не имеет практического значения.

В соответствии со статьей 16 Устава Большая Палата может передать дело на рассмотрение Пленума Суда ЕС, когда она считает, что это дело «большой важности», однако только после заслушивания мнения соответствующего генерального адвоката. Следовательно, основное правило заключается в том, что Суд ЕС самостоятельно решает, является ли конкретный вопрос настолько важным, чтобы рассматривать его на пленарном заседании: это обеспечивает гибкость механизма судопроизводства в Суде ЕС. Кроме того, в долгосрочной перспективе роль Большой Палаты в таком составе, как это предусмотрено новым Уставом, станет весьма значительной. После завершения процесса расширения Европейского Союза, когда, возможно, в его составе будет 25 государств-членов, станет реальностью одновременная работа двух Больших Палат ${ }^{31}$. Такое преобразование позволит Суду ЕС эффективно справляться с рассмотрением большего числа важных дел.

Однако расширение Европейского Союза и, соответственно, увеличение числа судей может привести к тому, что пленум Суда станет слишком многочисленным и неповоротливым для того, чтобы справляться со своими задачами. Кроме того, ни в Уставе, ни в договоре нет положений о том, как будет обеспечиватъся нечетное число судей, участву-

${ }^{3 !}$ Однако для этого потребуется пересмотр правила, согласно которому Председатель Суда ЕС должен председательствовать на заседаниях Большой Палаты, а раз такое правило закреллено в Уставе Суда ЕС, для его изменения потребуется единогласное решение Совета (ст. 245 ДЕС). Руководствуясь положениями, предусматривающими функционирование одной Большой Палаты, Рабочая Группа в своем докладе рассматривает возможность создания «постоянного представительства» в Большой Палате, а именно Председатель Суда ЕС и Председатели Палат, состояших из пяти судей. 
ющих в пленарном заседании, если в Состав Европейского Союза после расширения будет входить четное число государств, превышаюшее число судей, составляющее кворум на пленарном заседании. Очевидно, Совету потребуется вносить соответствующие поправки в Устав Суда ЕС.

В отношении состава СПИ статья 224 ДЕС определяет лишь минимальное число судей, которые должны входить в его состав: «Суд первой инстанции должен насчитывать, по крайней мере, по одному судье от каждого государства-члена», точное число судей должно быть зафиксировано в Уставе Суда ЕС. Следовательно, прямо закреплена возможность увеличивать число судей СПИ ${ }^{32}$ без необходимости вносить поправки в сам Договор, что полностью соответствует стремлению обоих судов позволить СПИ использовать большие судебные ресурсы для адекватного решения проблемы увеличивающегося потока дел. Сейчас, однако, статья 48 Устава Суда ЕС говорит лишь о пятнадцати судьях для СПИ. Точные условия увеличения количества судей по-прежнему являются предметом политической дискуссии.

Можно сделать вывод о том, что в отношении состава обоих судов Ниццский договор придерживается такого подхода, что любое увеличение численности судей, необходимое для того, чтобы суды легче справлялись с большей нагрузкой, которая ляжет на них после расширения Европейского Союза, возможно только на уровне СПИ и не затронет Суда ЕС. Малочисленный Суд ЕС, помимо пересмотра решений СПИ, будет по-прежнему компетентным рассматривать споры, которые имеют важное конституционное значение для Сообщества, а СПИ станет судом общей юрисдикции, рассматривающим по первой инстанции любые категории исков.

Помимо положений, касающихся непосредственно судей СПИ, статья 224 ДЕС говорит также о том, что Устав Суда ЕС может предусматривать учреждение в рамках СПИ института генеральных адвокатов. Вопрос о численности и роли генеральных адвокатов в Суде ЕС и СПИ не был урегулирован в ходе межправительственной конференции в Ницце. Возможность применения к числу генеральных адвока-

${ }^{32}$ Судья СПИ после внесения поправок, касающихся требуемой квалификации для занятия этой должности, должен отныне (в соответствии со ст. 224(2) ДЕС) иметь право быть назначенным на «высокие» судейские должности в своей стране: важное отражение существующей практики, которой придерживаются государства-члены при назначении судей; это также является дополнительным свидетельством (хотя и символическим, но не менее важным) постоянно укрепляющегося статуса СПИ. 
тов того же принципа равного представительства всех государств-членов (по одному генеральному адвокату от каждого государства) была отвергнута, и число генеральных адвокатов Суда ЕС осталось прежним, равным восьми. Однако Совет по требованию Суда ЕС может увеличить это число.

Новшеством, однако, явилось, как было сказано выше, включение в статью 224 ДЕС положения о том, что СПИ может иметь в своем составе генеральных адвокатов, если Устав Суда ЕС это предусматривает. До сих пор СПИ не имел в своем составе собственных генеральных адвокатов и очень редко пользовался правом назначать одного генерального адвоката из числа судей для рассмотрения конкретных дел. Закрепление такого положения является подтверждением важной роли, которую может сыграть мнение генерального адвоката в определенном деле, несмотря на то, что некоторые участники переговоров в Ницце указывали на тот факт, что отмена обязательного заслушивания мнения генерального адвоката по каждому делу поможет эффективно сократить время нахождения иска в производстве. Многие генеральные адвокаты сами придерживались мнения, что есть такие категории дел, как, например, иски о наложении штрафов на государства-члены, где представление генеральным адвокатом своего мнения является чистой формальностью и не служит никакой конструктивной цели. В этой связи статья 222 ДЕС разъясняет, что генеральный адвокат обязан представить свое мнение лишь в тех случаях, которые в соответствии с Уставом Суда ЕС требуют его вмешательства, что также является одной из попыток упрошения и ускорения рассмотрения дел в судах ЕС.

\section{5. Укрепление положения Европейского Парламента в сфере судопроизводства}

Ниццский договор значительно укрепляет позиции Европейского Парламента в сфере судопроизводства. Во-первых, Парламент наделяется статусом привилегированного истца по искам об аннулировании (новая статья 230 ДЕС), а во-вторых, полномочием запрашивать заключение Суда ЕС о соответствии учредительным договорам Сообщества соглашений, заключаемых Сообществом с третьими государствами или международными организациями, в рамках его консультативных полномочий в соответствии со статьей 300(6) ДЕС. 
Признание за Парламентом активной законодательной роли поначалу присутствовало лишь в судебной практике ${ }^{33}$. В любом случае Парламент мог подать в Суд ЕС иск об аннулировании только для защиты собственных прерогатив, тогда как такое ограничительное условие не было предусмотрено ни в отношении других институтов так называемого «институционального треугольника», ни в отношении государств-членов. Раз уж Парламент утверждается на европейском уровне как со-законодатель наравне с Советом Союза, логично было установить равновесие, наделив его полномочиями для подачи в Суд ЕС исков об аннулировании без каких-либо ограничений.

\section{6. Некоторые выводы}

В общих чертах, несмотря на революционный характер многих изменений, реформу судебной системы Сообщества, предпринятую Ниццским договором, можно признать очень осторожной. Многие важные проблемы, касаюшиеся в основном практической реализации новых положений, не были урегулированы в Договоре. Их решение отложено на будушее.

Одним из достижений реформы явилось, без сомнения, переосмысление роли Суда первой инстанции. Во-первых, он получил статус суда общей юрисдикции, который компетентен рассматривать по первой инстанции любые виды исков и наряду с Судом ЕС обеспечивать соблюдение права при толковании и применении положений учредительных актов Сообшества. Во-вторых, Ниццский договор закрепил положение, согласно которому СПИ может наделяться компетенцией в области преюдициального производства. Новшеством является создание специализированных судебных палат, которые призваны обеспечить быстрое и качественное рассмотрение споров с участием судей специалистов по определенным вопросам, как, например, патентное право, либо принять на себя всю нагрузку в сфере несущественных, но многочисленных споров, какими являются трудовые споры между служащими Сообщества и Сообшеством. Суд ЕС, таким образом, сохранил за собой статус квази-конституционного суда, рассматривающего споры, имеющие особую важность для европейского правопорядка в целом. Тем не менее, механизмы взаимодействия судов в До-

\footnotetext{
${ }^{33}$ Решение Суда ЕС от 22 мая 1990 г. по делу С-70.88 Parlement c./ Conseil.
} 
говоре урегулированы нечетко. При этом важную роль Ниццский договор отводит Уставу Суда ЕС. Благодаря тому, что изменения в Устав отныне могут вноситься единогласным решением Совета, без необходимости внесения изменений в учредительные документы, именно Устав Суда ЕС призван конкретизировать положения Договора, касающиеся функционирования судебной системы ЕС. Возможно, таким образом судебные органы Сообщества смогут быстрее адаптироваться к требованиям времени.

На межправительственной конференции в Ницце не было предпринято никаких попыток по упрощению или отмене закрепленного в статъе 230 ДЕС критерия для обращения в суды частных лиц, а именно критерия персональной направленности оспариваемого акта. С политической точки зрения это не удивительно и даже логично с точки зрения самой реформы: увеличение числа обращений в эти суды могло бы полностью свести на нет любые возможные улучшения. Тем не менее, Европейский Союз, заявляя о своем стремлении достичь наивысшего уровня в установлении «пространства свободы, безопасности и справедливости», без сомнения должен будет в будущем обратить большее внимание на эти существенные проблемные моменты, касающиеся доступа к правосудию, особенно потому, что влияние европейского права на повседневную жизнь граждан Европейского Союза постоянно возрастает. В контексте новой Хартии основных прав ЕС отрицание равной для всех и эффективной судебной защиты путем установления строгого критерия для обращения в суды Сообщества может стать причиной, способной привести к кризису доверия к судам Сообщества со стороны граждан Европейского Союза.

Сейчас трудно оценить, насколько нововведения, содержашиеся в Ниццском договоре, будут соответствовать тем целям, ради которых все и было задумано, а именно: обеспечение качественного отправления правосудия на уровне Сообщества и приспособление судебной системы к требованиям времени, особенно в перспективе грядущего расширения Европейского Союза. Однако важно то, что государствачлены выразили намерение предпринимать серьезные шаги в этом направлении и в будущем. 